Ann. Biol. anim. Bioch. Biophys., 1979, 19 (4 B), 1317-1325.

\title{
Effects of hCG and of season on in vitro steroidogenesis by 18-day chick embryo gonads.
}

par Arlette GUICHARD, Katy HAFFEN *, Lise CEDARD, Thérèse-Marie MIGNOT, Denise SCHEIB **

\author{
E. R. 123, Maternifé de Port-Royal, 123, bd de Port-Royal 75014 Paris \\ * Unité INSERM 61, 67200 Strasbourg Hautepierre \\ ** Institut d'Embryologie, CNRS ef Collège de France, 94130 Nogent sur Marne
}

Summary. Fragmented 18-day chick embryo gonads were explanted on synthetic media in the presence of hCG added to $24 \mathrm{~h}$ cultures at the beginning $(0 \mathrm{~h})$ and to $48 \mathrm{~h}$ cultures, only after $24 \mathrm{~h}$ or at 0 and $24 \mathrm{~h}$. The production of seven steroids was assayed by RIA and compared to that of control cultures containing no hCG. The levels were expressed as in vitro production per gonad (after deduction of the non-explanted gonadal content). When $5 \mathrm{IU}$ of hCG were added to the $24 \mathrm{~h}$ culture media at $0 \mathrm{~h}$, the overall steroidogenesis of the left and right gonads of both sexes increased significantly, the DHA in both sexes showing the most increment while $\Delta^{4}$-steroid (Prog. and $\Delta^{4}$-dione) production was not stimulated. Moreover, female gonad DHA production, as in the controls, was always higher than that of the testis. The female gonads produced mainly more $E_{2}$, while testis $T$ production was stimulated. Nevertheless, the discrepancy (observed earlier in the controls) between $T$ and $E_{2}$ balances of the left and right female gonads, and of the female and male gonads, was maintained under stimulation with female gonads and even increased with testis. A higher dose of hCG (15 IU), in these conditions, did not however further stimulate overall steroidogenesis. The effects on this and DHA production, observed with $5 \mathrm{IU}$ of $\mathrm{hCG}$, were not seen when that gonadotropin was given in vitro only after $24 \mathrm{~h}$. As compared to the $48 \mathrm{~h}$ control cultures, only $E_{2}$ was increased with both female gonads and $T$ with left testis. On the other hand, when hCG was given at both 0 and $24 \mathrm{~h}$ or only after $24 \mathrm{~h}, \Delta^{4}$-androstene-dione decreased, while this decrement was not seen in the $24 \mathrm{~h}$ cultures when hCG was given at $0 \mathrm{~h}$. There is probably a relation between the decrease of the $\Delta^{4}$-steroid and the $E_{2}$ increment which might be explained by hCG action on the aromatase process. However, a significant seasonal difference was seen during in vitro steroidogenesis by gonads of both sexes. This discrepancy mainly concerned overall steroidogenesis by gonads of 10 to 15-day embryos but not qualitative sex differences. The observation could be related to season-dependent precursor accumulation during oogenesis.

\section{Introduction.}

The in vitro production of steroids and sex hormones from radioactive precursors by chick embryo gonads has been largely demonstrated in recent years by incubation techniques (Galli and Wassermann, 1972, 1973) and organotypic cultures (Cedard and Haffen, 1966 ; Weniger et al., 1967 ; Guichard ef al., 1972). 
The presence of steroids in the gonads and their in vitro secretion has been verified recently by radioimmunological assays (Guichard et al., 1977 ; Teng and Teng, 1977). Our results have clearly defined the hormonal production abilities of both male and female gonads at different stages of embryological development. Female gonads produce estradiol while, owing to their restricted aromatizing capacity, the testes mainly secrete testosterone. A quantitative and qualitative difference in hormone secretion is observed between the left (ovary) and the right female gonads. Moreover, in vitro secretion can be enhanced by the addition of different steroid precursors of the sex hormones (Guichard et al., 1979, in press).

On the other hand, the hypophysis and hCG influence the gonads of bird embryos. Estrogen biosynthesis from radioactive acetate and DHA is stimulated in vitro by hCG, mainly with ovary of older embryos (Cedard ef al., 1968). Hypophyseal in vivo control of the gonads is seen at the testicular androgen level in embryos from 13-14 days (Woods et al., 1977). However, early hypophysectomy does not abolish the biological properties of 18-day male and female gonads (Akram and Weniger, 1969), and ovary is still able to produce in vitro estrogens from acetate (Akram et al., 1973).

The purpose of the investigations reported in this paper was to improve the direct effects of hCG on the production of different steroids, according to the sex and the side of the chick embryo gonad and to the time of culture at which the gonadotropin was added in vitro. We also present the seasonal differences in steroid production observed during our previous radioimmunological assay (RIA) of control cultures.

\section{Material and methods.}

Pieces of 18-day chick embryo gonads (5 gonads per Falcon dish) were explanted into organotypic cultures, and their secretion was tested by RIA as described earlier (Guichard et al., 1977). Synthetic media (Parker 199 without serum) and short-time cultures were used in order to avoid or limit in vitro the modifying effects on the explants of added or secreted products (Erickson, 1974 ; Carlon and Erickson, 1978). Moreover, media with embryo extracts do allow feminization by estrogens or androgens (Weniger and Zeis, 1973), while synthetic media do not (Stenger-Haffen, 1957). Five or $15 \mathrm{IU}$ of human gonadotropin (hCG) per Falcon dish $(0.8 \mathrm{ml})$ were added to the media in different conditions : at time 0 for $24 \mathrm{~h}$ cultures ( 5 series), and at 0 and $24 \mathrm{~h}$ ( 2 series) or only after $24 \mathrm{~h}$ ( 2 series) for $48 \mathrm{~h}$ cultures (media changed after $24 \mathrm{~h}$ ). The results were compared to controls explanted in the same conditions but without hCG.

The RIA's were performed simultaneously on several different steroids : progesterone (Prog.), $\Delta^{4}$-androstene-dione ( $\Delta^{4}$-dione), dehydroepiandrosterone (DHA), testosterone $(T)$, dihydrotesterone $(D H T)$, estrone $\left(E_{1}\right)$ and estradiol $\left(E_{2}\right)$. The results express the in vitro production per gonad in 24 or $48 \mathrm{~h}$; they were obtained by subtracting the level of gonads removed at the same time, but not explanted, from the in vitro steroid content (explants + media). 


\section{Results.}

a) Addition of 5 or $15 \mathrm{IU}$ of hCG at the beginning of $24 \mathrm{~h}$ culture (fig. 1, table 1).

The total production of the seven steroids assayed (fig. 1) was significantly enhanced $(P<0.05)$ in the presence of $5 \mathrm{IU}$ of the gonadotropin in the left as well as in the right gonad of both sexes (ovary : 24 p. 100 ; right female gonad : 38.7 p. 100 ;

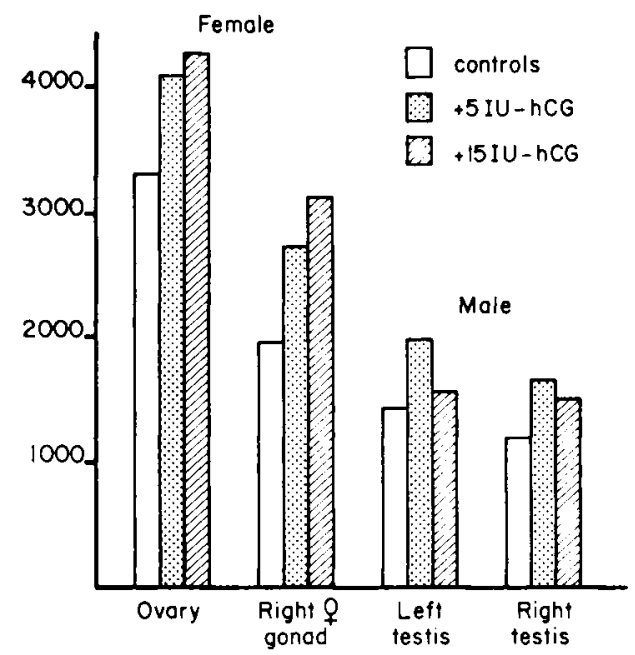

FIG. 1. - Compared in vitro effects of hCG (5 or 15 IU) on steroidogenesis by 18-day chick embryo gonads.

The data express in $\mathrm{pg} / \mathrm{gonad} / 24 \mathrm{~h}$ the total production of the seven steroids assayed.

TABLE 1

In vitro production of different steroids by 18-day chick embryo gonads explanted 24 hrs when 5 or 15 IU of hCG are added at the onset of culture. Data are expressed in $\mathrm{pg} / \mathrm{gonad} / 24 \mathrm{~h}$

\begin{tabular}{|c|c|c|c|c|c|c|c|c|c|c|}
\hline & & & $\mathrm{DHA}$ & Prog & $\Delta^{4}$-dione & $E_{1}$ & $E_{2}$ & $\mathbf{T}$ & DHT & Total \\
\hline \multirow{2}{*}{9} & $\begin{array}{c}\text { Left } \\
\text { (ovary) }\end{array}$ & $\begin{array}{l}\text { Control } \\
+5 \mathrm{IU} \\
+15 \mathrm{IU}\end{array}$ & $\begin{array}{r}666 \\
1374 \\
885\end{array}$ & $\begin{array}{l}679 \\
435 \\
501\end{array}$ & $\begin{array}{l}304 \\
320 \\
468\end{array}$ & $\begin{array}{l}282 \\
274 \\
414\end{array}$ & $\begin{array}{r}906 \\
1155 \\
1449\end{array}$ & $\begin{array}{l}315 \\
441 \\
373\end{array}$ & $\begin{array}{l}145 \\
103 \\
191\end{array}$ & $\begin{array}{l}3297 \\
4102 \\
4281\end{array}$ \\
\hline & $\begin{array}{l}\text { Right } \\
\text { gonad }\end{array}$ & $\begin{array}{l}\text { Control } \\
+5 \mathrm{IU} \\
+15 \mathrm{IU}\end{array}$ & $\begin{array}{r}378 \\
1290 \\
860\end{array}$ & $\begin{array}{l}365 \\
129 \\
351\end{array}$ & $\begin{array}{l}283 \\
202 \\
340\end{array}$ & $\begin{array}{l}148 \\
161 \\
191\end{array}$ & $\begin{array}{l}304 \\
371 \\
736\end{array}$ & $\begin{array}{l}414 \\
458 \\
587\end{array}$ & $\begin{array}{r}63 \\
115 \\
58\end{array}$ & $\begin{array}{l}1965 \\
2726 \\
3123\end{array}$ \\
\hline \multirow{2}{*}{ o } & $\begin{array}{l}\text { Left } \\
\text { testis }\end{array}$ & $\begin{array}{l}\text { Control } \\
+5 \mathrm{IU} \\
+15 \mathrm{IU}\end{array}$ & $\begin{array}{l}305 \\
653 \\
369\end{array}$ & $\begin{array}{l}340 \\
290 \\
273\end{array}$ & $\begin{array}{l}227 \\
199 \\
259\end{array}$ & $\begin{array}{l}69 \\
46 \\
84\end{array}$ & $\begin{array}{l}30 \\
32 \\
57\end{array}$ & $\begin{array}{l}319 \\
698 \\
424\end{array}$ & $\begin{array}{r}133 \\
78 \\
92\end{array}$ & $\begin{array}{ll}1423 \\
1996 \\
1558\end{array}$ \\
\hline & $\begin{array}{l}\text { Right } \\
\text { testis }\end{array}$ & $\begin{array}{l}\text { Control } \\
+5 \mathrm{IU} \\
+\quad 15 \mathrm{IU}\end{array}$ & $\begin{array}{l}281 \\
779 \\
337\end{array}$ & $\begin{array}{r}153 \\
98 \\
233\end{array}$ & $\begin{array}{l}223 \\
141 \\
343\end{array}$ & $\begin{array}{l}54 \\
36 \\
65\end{array}$ & $\begin{array}{l}19 \\
14 \\
13\end{array}$ & $\begin{array}{l}348 \\
669 \\
448\end{array}$ & $\begin{array}{r}111 \\
66 \\
67\end{array}$ & $\begin{array}{l}1189 \\
1662 \\
1506\end{array}$ \\
\hline
\end{tabular}


left or right testis : about 40 p. 100). However, a threefold dose of hCG (15 IU) did not, in these conditions, further stimulate steroid synthesis at the same rate (ovary : 30 p. 100; right female gonad : 50 p. 100) ; testicular steroid synthesis showed a lesser increase. For this reason, we centered our observations mainly on the results obtained with 5 IU of hCG.

If we now consider the production of the different steroids assayed (table 1), it appears that with gonads of both sexes and sides, the DHA was mainly increased $\left(P<0.02\right.$ ), while the $\Delta^{4}$-steroids (Prog., $\Delta^{4}$-dione) were not. The $D H A$ level rose 106 p. 100 with left female gonad and 241 p. 100 with right female gonad, and 114 p. 100 with left festis and 177 p. 100 with right testis.

Concerning sex hormone production, there was an increase in female gonad estradiol $\left(E_{2}\right)$ (ovary : 27 p. 100 ; right gonad : 22 p. 100), while the estrogens $\left(E_{2}\right.$ and $\left.E_{1}\right)$ were not increased in testes. The testosterone production was more enhanced with both testes (left : 118 p. 100 ; right : 92 p. 100) than with female gonads (ovary : 40 p. 100 ; right gonad : 10 p. 100 ).

Moreover, the discrepancy observed earlier between the hormonal balances $\left(E_{2}\right.$ and $\left.T\right)$ (Guichard et al., 1977) of the left and right female gonads, and of the female and male gonads, was maintained during in vitro stimulation. Compared to female gonads, the $T / E_{2}$ ratio was high in male gonads, and even increased, when stimulated by hCG, from 10.6 to 21.8 for left testis and from 18.3 to 47.7 for right testis. On the other hand, the $E_{2} / T$ ratio in female gonads was maintained during stimulation : 2.87 and 2.61 , respectively, for control and stimulated ovaries, 0.73 and 0.81 for control and stimulated right gonads. Once more, it appeared that the rudimentary right gonads produced a rather high level of testosterone when compared to their estrogen production and to that of ovarian testosterone.

b) Addition of hCG in $48 \mathrm{~h}$ cultures (table 2).

TABLE 2

Effects of hCG on steroidogenesis by 18-day chick embryo gonads explanted $48 \mathrm{~h}$.

The gonadotropin (5 IU) is added in vitro only after $24 \mathrm{~h}$ (B) or at 0 and $24 \mathrm{~h}$ (C) ; the data are expressed in $\mathrm{pg} / \mathrm{gonad} / 48 \mathrm{~h}$

\begin{tabular}{|c|c|c|c|c|c|c|c|c|c|c|}
\hline & & & DHA & Prog. & $\Delta^{4}$-dione & $E_{1}$ & $E_{2}$ & $T$ & DHT & Total \\
\hline \multirow{2}{*}{ 우 } & $\begin{array}{c}\text { Left } \\
\text { (ovary) }\end{array}$ & $\begin{array}{c}\text { Control (A) } \\
+ \text { hCG (B) } \\
+ \text { hCG (C) }\end{array}$ & $\begin{array}{r}2064 \\
707 \\
2534\end{array}$ & $\begin{array}{l}846 \\
623 \\
965\end{array}$ & $\begin{array}{l}710 \\
699 \\
247\end{array}$ & $\begin{array}{r}532 \\
562 \\
1374\end{array}$ & $\begin{array}{r}645 \\
2976 \\
4755\end{array}$ & $\begin{array}{r}423 \\
395 \\
1062\end{array}$ & $\begin{array}{l}432 \\
265 \\
129\end{array}$ & $\begin{array}{r}5652 \\
6227 \\
10866\end{array}$ \\
\hline & $\begin{array}{l}\text { Right } \\
\text { gonad }\end{array}$ & $\begin{array}{c}\text { Control (A) } \\
+ \text { hCG (B) } \\
+h C G(C)\end{array}$ & $\begin{array}{r}1742 \\
403 \\
2396\end{array}$ & $\begin{array}{l}466 \\
141 \\
488\end{array}$ & $\begin{array}{r}2774 \\
588 \\
37\end{array}$ & $\begin{array}{l}309 \\
337 \\
615\end{array}$ & $\begin{array}{r}533 \\
1311 \\
2644\end{array}$ & $\begin{array}{l}368 \\
398 \\
472\end{array}$ & $\begin{array}{l}322 \\
175 \\
163\end{array}$ & $\begin{array}{l}6514 \\
3053 \\
6815\end{array}$ \\
\hline \multirow{2}{*}{ ठ } & $\begin{array}{l}\text { Left } \\
\text { testis }\end{array}$ & $\begin{array}{c}\text { Control (A) } \\
+h C G(B) \\
+h C G(C)\end{array}$ & $\begin{array}{r}1820 \\
173 \\
1805\end{array}$ & $\begin{array}{l}387 \\
153 \\
290\end{array}$ & $\begin{array}{r}1437 \\
551 \\
82\end{array}$ & $\begin{array}{r}310 \\
90 \\
134\end{array}$ & $\begin{array}{r}32 \\
0 \\
144\end{array}$ & $\begin{array}{r}304 \\
428 \\
1057\end{array}$ & $\begin{array}{r}249 \\
0 \\
416\end{array}$ & $\begin{array}{l}4539 \\
1395 \\
3928\end{array}$ \\
\hline & $\begin{array}{l}\text { Right } \\
\text { testis }\end{array}$ & $\begin{array}{c}\text { Control (A) } \\
+h C G(B) \\
+h C G(C)\end{array}$ & $\begin{array}{r}1422 \\
84 \\
1668\end{array}$ & $\begin{array}{r}342 \\
211 \\
85\end{array}$ & $\begin{array}{r}844 \\
504 \\
12\end{array}$ & $\begin{array}{r}142 \\
110 \\
87\end{array}$ & $\begin{array}{r}23 \\
0 \\
18\end{array}$ & $\begin{array}{l}521 \\
502 \\
675\end{array}$ & $\begin{array}{r}327 \\
397 \\
51\end{array}$ & $\begin{array}{l}3621 \\
1908 \\
2596\end{array}$ \\
\hline
\end{tabular}


In the second experimental group we tested the in vitro effects of the gonadotropin on cultures lasting $48 \mathrm{~h}$ (medium changed after $24 \mathrm{~h}$ ). In two experiments, $5 \mathrm{IU}$ of hCG were added only after $24 \mathrm{~h}(\mathrm{~B})$; while in the other two it was added both at 0 and $24 \mathrm{~h}(\mathrm{C})$. The data were compared to the control explants cultured in the same conditions without hCG (A).

When hCG was supplied only $24 \mathrm{~h}$ after the onset of the culture (B), the levels of the global steroid production decreased by about 50-60 p. 100 of that of the controls, except for ovary. However, with this delayed hCG action, $E_{2}$ mainly increased with both female gonads, while testicular estrogens $\left(E_{1}\right.$ and $\left.E_{2}\right)$ dropped. In these conditions, all the other steroids (mainly DHA) tended to decrease ; testosterone production was somewhat enhanced (40 p. 100) only with left testis.

When hCG was added both at 0 and $24 \mathrm{~h}(\mathrm{C})$, the total production of the seven steroids assayed was significantly increased $(P<0.05)$ only with ovary $(108$ p. 100). However, the levels of some hormones rose with the different gonads. This observation concerned chiefly $E_{2}$ with ovary (637 p. 100) and right gonad (396 p. 100) and even left testis (350 p. 100), but in the latter the levels remained low in comparison to that of female gonads. Testosterone was also increased mainly with left testis (247 p. 100) and ovary (151 p. 100), but less with right female (28 p. 100) and male (41 p. 100) gonads. In these conditions, DHA did not drop as above (B), and progesterone levels were not significantly modified while that of $\Delta^{4}$-dione decreased drastically.

c) Seasonal influence on hormone production (fig. 2).

During our numerous investigations using RIA on in vitro steroidogenesis by chick embryo gonads, spread over more than two years, we noticed large quantitative variations in the data which depended on the season at which the gonads were explanted. So, we decided to examine this point more closely and to classify the results into two groups, one covering the short daylight season (winter gonads : 15 September-15 March) and the other the longer photoperiod season (summer gonads : 15 March-15 September).

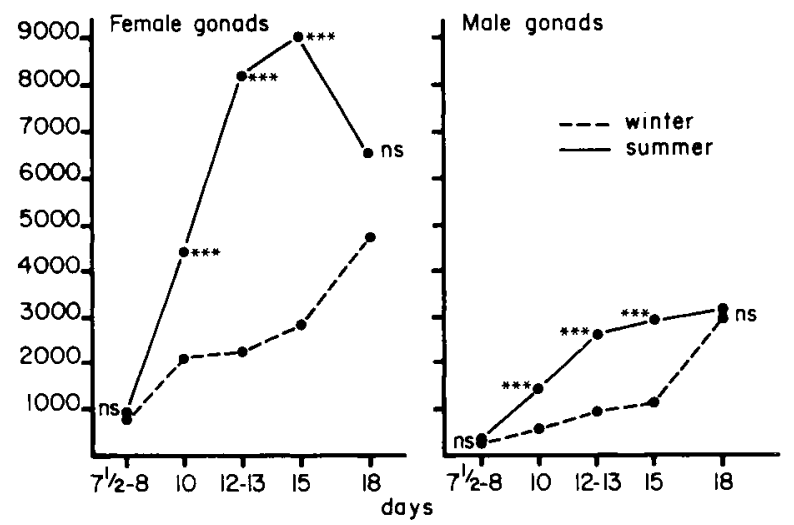

FIG. 2. - Compared seasonal differences in steroidogenesis by gonads of female and male embryos ( $71 / 2$ to 18 days). The data express total in vitro production in $\mathrm{pg} /$ gonads (left + right) for $24 \mathrm{~h}$ cultures. 
It appeared in both sexes that the total steroid production by summer gonads was much higher than that of winter gonads (fig. 2). This difference was highly significant $(P<0.05)$ for gonads of 10,12 and 15-day embryos, and it was not observed at the beginning of sexual differentiation (71/2 days) or towards the end of incubation.

Female gonads of 10 to 18 days always produced more estrogens in summer than in winter, and much more at any season than the testes. However, season and sex variations in testosterone levels were not significantly different : they were higher in summer for 15 and 18-day female gonads and in winter for 8 to 12-day testes.

\section{Discussion.}

The present results demonstrate that hCG can stimulate in vitro the spontaneous steroidogenesis of 18-day chick embryo gonads. The gonadotropic action was more effective when the gonadotropin was added at the beginning of 24 or $48 \mathrm{~h}$ cultures than only after a delay of $24 \mathrm{~h}$ : the total steroid production was increased, and mainly that of DHA for both sexes.

For female gonads the stimulation concerned mainly $E_{2}$ production. This result confirmed those obtained in the presence of radioactive precursors (Cedard ef al., 1968), and has also been observed in short in vitro incubations with 8 to 18-day chick embryo gonads (Teng and Teng, 1977). Testosterone production increased most with the testes.

hCG acts on pregnenolone formation from esterified cholesterol. This was confirmed for post-hatching 7-day testis in which esterified cholesterol was significantly reduced with hCG (Massa and Aoki, 1976) ; in the embryo the interstitial cells of male and female gonads also contain such esterified cholesterol (Scheib, 1959). Our results suggest that hCG has an effect on cholesterol utilization which could be caused by cholesterol-esterase or 20-22 cholesterol hydroxylase stimulation, leading to an increased endogenous pregnenolone production. It has also been demonstrated that hCG can stimulate in vitro cholesterol formation from acetate by chick embryo gonads (Haffen ef al., 1969).

Moreover, our different data do not indicate an immediate and direct effect of hCG on the $\Delta^{5}-3 \beta$ HSDH enzymatic system, and some results obtained with rat testis show that in vivo hCG needs some time to act on the $\Delta^{5}-3 \beta$ oxydoreductase (Wiebe, 1978). In the chick embryo, the gonads are under hypophysal control from 14 days on, as shown by the level of $\Delta^{5}-3 \beta$ HSDH activity in ovaries (Woods and Weeks, 1969) and by that of testicular androgens (Woods et al., 1977) which decrease after early hypophysectomy.

The very significant increase of DHA and testosterone, chiefly by male embryo gonads, confirms results obtained with 2-day old chick testis, in which testosterone biosynthesis from acetate goes through DHA and is stimulated by hCG (Connel ef al., 1966).

The increased estrogen production with a drop of the $\Delta^{4}$-androstene-dione level suggests that hCG acts on aromatizing enzymes; this has also been observed previously with radioactive DHA (Cedard et al., 1968).

The seasonal differences in the hormone production capacities of chick gonads from embryos not submitted to photoperiod or maternal influence at first glance seem 
rather surprising. As these differences are greatest at 12-15 days, and not at 18 days, they are probably not due to embryonic hypophysis activity. The higher metabolic rate of the gonads may be linked to an egg precursor supply which is determined in the hen during ovogenesis; the yolk has been shown to contain different enzymes transforming the precursors of steroidogenesis (Delrio et al., 1968). Moreover, estrogens can be transferred in vivo to the eggs in laying ring doves and lead to feminization of the embryos (Riddle and Dunham, 1942) ; also, injected radioactive estrogens in laying hens are transferred to their eggs (Arcos, 1972). Season may as well influence the relative proportion of active and inactive theca cells in the duck ovary (Deray and Gomot, 1978).

The technique of the organotypic culture of gonads on synthetic media, combined with radioimmunoassay, is a reliable experimental model for in vitro studies of steroid biosynthesis capacities and for investigating the direct effects of various factors.

4th Workshop on « Development and maturation of the reproductive organs and functions " Luynes, France, octobre 1978.

Acknowledgments. - This research was supported by a DGRST grant No 77-7-0651.

Résumé. Des gonades d'embryons de Poulet de 18 jours ont été cultivées sur milieux synthétiques, en présence de HCG ajouté dans différentes conditions. La production de 7 stéroïdes a été estimée par dosages radioimmunologiques ef comparée à celle de gonades explantées en absence de HCG. Les valeurs expriment pour $24 \mathrm{~h}$ ou $48 \mathrm{~h}$, la production in vitro (explants + milieux) en $\mathrm{pg} /$ gonade (après déduction des teneurs en stéroïdes de gonades non cultivées).

L'adjonction de 5 UI de HCG au début de cultures de 24 h stimule la production globale des stéroïdes, dans les gonades gauches ef droites des deux sexes. L'augmentation la plus forte se situe au niveau de la synthèse de la DHA dont les taux sont toujours plus élevés pour les gonades femelles que pour les testicules; les $\Delta^{4}$-stéroïdes (Prog. et $\Delta^{4}$-dione) ne sont, par contre, pas concernés par cette stimulation. Au niveau de la secrétion hormonale, les gonades femelles produisent surtout plus de $E_{2}$ ef les testicules plus de $T$. L'équilibre entre ces deux stéroïdes $\left(E_{2} / T\right)$ n'est pas modifié pour les gonades femelles ef reste toujours plus élevé dans l'ovaire que dans la gonade droite. Pour les testicules, le rapport élevé $T / E_{2}$ est encore augmenté après stimulation par HCG. L'adjonction d'une dose triple de HCG (15 UI) n'augmente cependant pas en rapport la production hormonale.

Les effets de HCG $(5 \mathrm{UI}$ ) ajouté seulement après $24 \mathrm{~h}$ (cultures de $48 \mathrm{~h}$ ) révèlent que la production globale augmente seulement pour l'ovaire et celle de $E_{2}$ uniquement pour les gonades femelles. A part le testicule gauche, la synthèse de $T$ n'est pas stimulée dans ces conditions.

Par contre, si on fournit aux explants 5 UI de HCG à la fois au départ et après $24 \mathrm{~h}$ de culture, on observe surtout une chute de la $\Delta^{4}$-dione parallèle à une augmentation des œstrogènes ef surtout de $E_{2}$ pour les gonades femelles, ce qui indique pour ce sexe une stimulation de l'aromatisation par HCG.

Enfin, une différence saisonnière significative de la stéroïdogenèse in vitro par les gonades embryonnaires est observée pour les stades de 10 à 15 jours. Pour les deux sexes, la production globale est nettement plus élevée au printemps-été et il en est de même pour les œstrogènes par les gonades femelles. Ces résultats suggèrent l'existence de capacités endogènes des gonades, variables avec les saisons, ef probablement transmises à l'œuf pendant l'ovogenèse. 


\section{References}

AKRAM H., WENIGER J. P., 1969. Activité hormonale des gonades d'embryons de poulet hypophysectomisés. J. Emb. exp. Morph., 21, 509-515.

AKRAM H., ZEIS A., WENIGER J. P., 1973. Biosynthèse d'œstrogènes par l'ovaire de l'embryon Je poulet hypophysectomisé : aspect quantitatif, C. R. Acad. Sci. Paris, Sér. D., 276, 359-361.

ARCOS M., 1972. Steroids in egg yolk. Steroids, 19, 25-35.

CARLON N., ERICKSON G. F., 1978. Fine structure of prefollicular and developing germ cells in the male and female left embryonic chick gonads in vitro with and without androgenic steroids. Ann. Biol. anim. Bioch. Biophys., 18, 335-349.

CEDARD L., HAFFEN K., 1966. Transformation de la déhydroépiandrostérone par les gonades embryonnaires de poulet cultivées in vitro. C. R. Acad. Sci., Paris, Sér. D., 263, 430-433.

CEDARD L., HAFFEN K., GUICHARD A., 1968. Influence de l'hormone gonadotrope chorionique sur la production d'œstrogènes à partir d'acétate de $\mathrm{Na}$ et de déhydroépiandrostérone radioactifs par les gonades embryonnaires de poulet, cultivés in vitro. C. R. Acad. Sci., Paris, Sér, D., 267, 118-120.

CONNELL G. M., CONNELL C. J., EIK-NES, K. B., 1966. Testostérone synthesis by the two day old chick testis in vitro. Gen. comp. Endocr., 7, 158-165.

DELRIO G., BOTTE V., LUPO DI PRISCO C., 1968. Ricerca degli enzimi della Steroidogenese nel vitello dell'uovo di gallus domesticus. Rend. Accad. Lincei, 45, 616-619.

DERAY A., GOMOT L., 1978. Les cellules stéroidogènes à activité $3 \beta$-hydroxystéroïde déshydrogénasique $(3 \beta-H S D)$ des ovaires de canes Pékin, Barbarie et hybrides (Pékin $\delta \times$ Barbarie 9 ). Caractères spécifiques et variations saisonnières. Biol. cell., 31, 91-100.

ERICKSON G. F., 1974. "Spontaneous » sex reversal in organ cultures of the embryonic male gonad of the bird. J. Embryol. exp. Morph., 31, 611-620.

GALLI F. E., WASSERMANN G. F., 1972. Steroid biosynthesis by testes and ovaries of 15 day-old chick embryos. Gen. comp. Endocr., 19, 509-515.

GALLI F. E., WASSERMANN G. F., 1973. Steroid biosynthesis of 7- and 10 day old chick embryos. Gen. comp. Endocr., 21, 77-83.

GUICHARD A., CEDARD L., HAFFEN K., 1973. Aspect comparatif de la synthèse de stéroïdes sexuels par les gonades embryonnaires de poulet à différents stades du développement (étude en culture organotypique à partir de précurseurs radioactifs). Gen. comp. Endocr., 20, 16-28.

GUICHARD A., CÉDARD L., MIGNOT Th. M., SCHEIB D., HAFFEN K., 1979. Radioimmunoassay of steroids produced by cultured chick embryonic gonads : differences according to age, sex and side. Gen. comp. Endocr., 32, 255-265.

GUICHARD A., 1978. Ełude de la stéroïdogenèse par les gonades embryonnaires d'oiseaux. Thèse Doct. Sci. Nat., Paris.

GUICHARD A., CEDARD L., MIGNOT M. Th., SCHEIB D., HAFFEN K., 1978. Radioimmuno assays of steroids produced by chick embryo gonads cultured in presence of some precursors (to be published at Gen. comp. Endocr.).

HAFFEN K., CEDARD L., GUICHARD A., 1969. Formation de cholestérol radioactif à partir d'acétate de $\mathrm{Na}-1-{ }^{14} \mathrm{C}$ par les gonades embryonnaires de poulet, cultivées in vitro. C. R. Acad. Sci., Paris, Sér. D., 268, 2914-2917.

MASSA E. M., AOKI A., 1976. Differentiation of cholesterol compartments in the immature chick testis. J. Reprod. Fertil., 47, 313-318.

RIDDLE O., DUNHAM H. H., 1942. Transformation of males to intersexes by estrogen passed from blood of ring doves to their ovarian eggs. Endocrinology, 30, 959-968.

SCHEIB D. 1959. Sur la détection des lipides figurés dans les gonades de l'embryon de poulet. Distribution, nature et signification de ces substances. Annales Histoch., 4, 33-50.

STENGER-HAFFEN K., 1957. Etude des besoins nutritifs des gonades embryonnaires d'oiseau cultivées en milieux synthétiques. Arch. Anat. micr. Morph. exp., 46, 521-607.

TENG C. T., TENG C. S., 1977. The hormonal regulation of steroidogenesis and adenosine 3' : 5'-cyclic monophosphate in embryonic chick ovary. Biochem. J., 162, 123-134. 
WENIGER J. P., EHRHARDT J. D., FRITIG B., 1967. Sur la formation d'œstrone el d'œstradiol par les gonades de l'embryon de poulet cultivées in vitro. C. R. Acad. Sci., Paris, Sér. D., 264, 838-841.

WENIGER J. P., ZEIS A., 1973. Action féminisante des androgènes sur le testicule ef le canal de Müller d'embryon de poulet. Arch. Anat. micr. Morph. exp., 62, 145-150.

WIEBE J. P., 1978. Steroidogenesis in rat Leydig cells : effect of gonadotropins on the activity of 5 -ane and 5-ene- 3 and $3 \alpha$ - and $3 \beta$ hydroxysteroid dehydrogenase during sexual maturation. Endocrinology, 102, 775-784.

WOODS J. E., WEEKS R. L., 1969. Ontogenesis of the pitoitary-gonadal axis in the chick embryo. Gen. comp. Endocr., 13, 242-254.

WOODS J. E., PODCZASKI E. S., ERTON L. H., RUTHERFORD J. E., Mc CARTER C. F., 1977. Establishment of the adenohypophyseal testicular axis in the chick embryo. I. Testicular androgen levels. Gen. comp. Endocr.. 32, 390-394. 